\title{
On Farm Validation of Technology Packages for Supporting Durum Wheat Extension Package Formulation in Ethiopia
}

\author{
Wasihun Legesse ${ }^{1, *}$, Aklilu Nigussie ${ }^{2}$ \\ ${ }^{1}$ Ethiopian Institutes of Agricultural Research, Debre-Zeit Agricultural Research Center, Department of Crop Science Research-Durum \\ Wheat-Projec, Addis Ababa, Ethiopia \\ ${ }^{2}$ Ethiopian Institutes of Agricultural Research, Debre-Zeit Agricultural Research Center, Department of Agricultural Economics Research, \\ Addis Ababa, Ethiopia
}

Email address:

wasihunl@yahoo.com (W. Legesse), akli12002@yahoo.com (A. Nigussie)

${ }^{*}$ Corresponding author

\section{To cite this article:}

Wasihun Legesse, Aklilu Nigussie. On Farm Validation of Technology Packages for Supporting Durum Wheat Extension Package Formulation in Ethiopia. Journal of Plant Sciences. Vol. 8, No. 3, 2020, pp. 57-66. doi: 10.11648/j.jps.20200803.12

Received: March 17, 2020; Accepted: April 20, 2020; Published: June 8, 2020

\begin{abstract}
This study aims at assessing three different packages for their benefits to the farmer's extension intervention, based on the economic benefit to maximize profit gains. The comparisons of average differences in the on farm economic performance of the packages applied are compared to each other with cost and benefits using variable cost for production season of durum wheat producers. The result of one year on farm cost of production for the three packages varies accordingly; the total variable cost (TVC) per $\mathrm{h}^{-1}$ was found 14,645.25, 16,888.50 and 14,645.25 Ethiopian Birr for extension, ATA and farmer packages while the grain yield was found 3830,4010 and $3130 \mathrm{Kg}$ respectively. The net revenue gains from grain yield and straw was found 53,498 Birr from extension package; 54,600 Birr from ATA package and 41,126 Birr from farmer practiced trials. From the $\mathrm{h}^{-1}$ on farm trials with the recommended packages durum production was found profitable the net profit was found all attractive as the cost incurred didn't outweigh the benefits gain. The price of grain yield at the present market prices was 17.00 Birr per $\mathrm{Kg}$; while the straw price per $\mathrm{Kg}$ was found $3.75 \mathrm{Birr}$; on the other side seed price per $\mathrm{Kg}$ was 17 Birr. The break-even price for extension, ATA, and farmer practice packages varies as they had difference TVC, grain yield and TRV.
\end{abstract}

Keywords: Yield, TVC, Break-even Price, Break-even Yield, MRR

\section{Introduction}

Durum is a tetraploid species of wheat [1]. It is the second most cultivated species of wheat after common wheat, although it represents only $5 \%$ to $8 \%$ of global wheat production [2]. There are six types of Triticum species[3], of which Triticumaestivum and Triticumturgidum are the most dominantly grown species in Ethiopia. Triticum durum was believed to be originated thousands of years ago from hybridization between the wild diploid T. monococcum L. subsp. and T. speltoides (Tauschi) Gren; or its closely related species [3]. Ethiopia is believed to be secondary center of diversity of the crop. A very large amount of genetic diversity exists for this crop [4]. Naked emmer reached Ethiopia approximately 5000 years ago [5], probably arriving from the Levantine, through Egypt, along the Silk Road [6]. Today emmer wheat occupies approximately $7 \%$ of the wheat production in Ethiopia under the local name of aja. Recent molecular data [7] indicated that Ethiopian farmers repeated what had been achieved already in West Asia before, by deriving durum wheat anew through the further domestication of emmer. This new origin of the same crop gave rise to a subspecies known as $\mathrm{T}$. turgidum ssp. aethiopicum or abyssinicum. Until relatively recently, landraces belonging to this subspecies were widely cultivated by smallholder farmers in Ethiopia, with up to $80 \%$ of the total durum land farmed with these unique biotypes [8].

Ethiopia is the largest producer of durum wheat, with approximately 0.6 million ha [9], but national average yield of durum wheat is low $2.4 \mathrm{tha}^{-1}[10]$

As it is known world wide, Durm wheat is good for pasta 
making better than common wheat because of its nature. In Ethiopia when there is low production of durum wheat, there is a common trande of using common wheat for making pasta. Durum in Latin means "hard", and the species is the hardest of all wheats. This refers to the resistance of the grain to milling, in particular of the starchy endosperm; implying dough made from its flour is weak or "soft". This makes durum favorable for semolina and pasta and less practical for flour, which requires more work than with hexaploid wheats like common bread wheats. Despite its high protein content, durum is not strong wheat in the sense of giving strength to dough through the formation of a gluten network. Durum contains $27 \%$ extractable wet gluten, about $3 \%$ higher than in common wheat [11].

Durum flour and semolina are good for making pasta because they do not create doughs hard to shape, e.g. into sheets. Technically, the dough is relatively plastic, contrasting with the strong elastic doughs obtained from bread flours. Pure durum wheat breads are often dense, containing little air bubbles, with relatively little elastic structure (continuum). The uncooked dough splits easily and is easier to shape, as for instance to make pies or pastas [12].

The Ethiopian government is now pushing the farmers to produce more durum wheat to supply the agro industries for the production of high standard pasta. The government policy to be realized, the research system has developed many improved varieties. Up to now, 36 improved durum wheat varieties have been released [12]. Through the years of durum wheat breeding, genetic gain studies revealed that the average annual genetic gain in yield was $1.5 \%$ from 1966 to 2015 [13]. These varieties have been tested in many major durum wheat growing ares of the country with its full package and they were accepted by the farmers. Later on the agricultural transformation agency (ATA) brought an idea that these varieties when they are tested with the higher amount of fertilizer, they are more productive than what is reported by the research. Based on this information, the Ethiopian government suggested ATA recommendation to be validated.

The Agricultural transformation agency urea fertilizer recommendation in 2017 was $350 \mathrm{Kg} / \mathrm{ha}$. Whereas, the current urea fertilizer package for durum wheat is $250 \mathrm{Kg} / \mathrm{ha}$ for black soil and $200 \mathrm{Kg} / \mathrm{ha}$ for light soil. The ATA recommendation urea rate/ha has been increased from the current package with the assumption of increasing wheat yield of durum wheat. But this has to be validated by research. Therefore, the objectives of this experiment were:

1. To compare the yield advantage of ATA recommendation and the existing extension package.

2. To compare the benefit cost ratio of ATA recommendation and the extension package of durum wheat

\section{Material and Methods}

\subsection{Descriptions of Experimental Sites}

The experimental site was in Amhara region, Minjar shenkora district. The experiment was done in two on farm sites (Memhir ager and Sama sembet) with the altitude range of $1900-2000 \mathrm{~m}$. The experimental plot area was $20 \mathrm{~m} \times 25 \mathrm{~m}$ with a total area of $500 \mathrm{~m}^{2}$ for each treatment/recommendation package. The type of soil was black. The durum wheat recommendation package validation trial had three recommendation package types using a common utuba durum wheat variety (Table 1).

1. The ATA recommendation package: $300 \mathrm{Kg}$ UREA, two third at planting and one third 35 days after planting. $100 \mathrm{Kg}$ NPS fertilizer at planting. Fungicide application for rust disease was done without considering the prevailing condition of the disease. Palace herbicide was used for weed (Table 1)

2. Extension package recommendation: $250 \mathrm{Kg}$ UREA, one third at planting and two third 35 days after planting. $100 \mathrm{Kg}$ NPS fertilizer at planting. Fungicide application for rust disease was when it is necessary (Table 1).

Table 1. Recommended packages of ATA, extension and farmers' practice with extension package.

\begin{tabular}{|c|c|c|c|c|c|c|c|c|}
\hline \multicolumn{4}{|l|}{ Fertilizer } & \multicolumn{5}{|c|}{ Pesticide/herbicides } \\
\hline \multirow{2}{*}{ Experiments } & \multicolumn{2}{|l|}{ Rate } & \multirow{2}{*}{$\begin{array}{l}\text { Time of application } \\
\text { UREA }\end{array}$} & \multirow{2}{*}{$\begin{array}{l}\text { Rust disease } \\
\text { Pesticide }\end{array}$} & \multirow{2}{*}{$\begin{array}{l}\text { Weed } \\
\text { Herbicide }\end{array}$} & \multirow[t]{2}{*}{ Rate } & \multicolumn{2}{|c|}{ Time of application } \\
\hline & UREA & NPS & & & & & Pesticide & Herbicide \\
\hline ATA package & $300 \mathrm{Kg}$ & $100 \mathrm{Kg}$ & $2 / 3$ at planting, $1 / 3$ at 35 days after planting & Rexdo & Pallas & $\begin{array}{l}0,5 \\
1 \mathrm{t} / \mathrm{ha}\end{array}$ & $\begin{array}{l}\text { At } 45 \text { days } \\
\& \text { heading }\end{array}$ & $\begin{array}{l}\text { At } 30 \\
\text { days }\end{array}$ \\
\hline Extension package & $250 \mathrm{Kg}$ & $100 \mathrm{Kg}$ & $1 / 3$ at planting, $2 / 3$ at 35 days after planting & & Manual & & & \\
\hline Farmers` practice & $250 \mathrm{Kg}$ & $100 \mathrm{Kg}$ & $2 / 3$ at planting, $1 / 3$ at 35 days after planting & & Manual & & & \\
\hline
\end{tabular}

Source: Trial experiments on recommendations 2019

\subsection{Data Collection}

Relevant agronomic and cost data were collected from the experimental trial. Primary data on grain yield, above ground biomass, straw, labor and oxen rent, and application rates of inputs such as seed, fertilizer and pesticides were based on recommendations used for the trial. Data were initially calculated for each farmer separately and then combined across three locations. All costs and revenues were quantified based on $500 \mathrm{~m}^{2}$ and converted to hectare base; furthermore mean extrapolated to the hectare basis.

\subsection{Data Analyses}

Analysis of variance was carried in the agronomic data (grain yield, aboveground biomass and straw yield) using the two test sites as replications in a randomized complete block design. Partial budget was calculated for each four treatment by estimating the value of production, which gives the gross 
benefit, the costs of different inputs applied, and eventually calculating the net benefit for each of the treatments. The marginal rate return (MRR) for each treatment was calculated as the ratio of additional net benefit to the extra cost resulting from the adoption of increasing level of input.

The two concepts of analysis followed in this research were:-

1. Partial budget approach indicates the net benefit characteristic to change in different treatments. Cost or return items which remain constant were not included in the analysis.

2. Marginal analysis method designates the increase in cost and in income obtained by stirring from one treatment or combination to another. These make it possible to categorize the point at which a given increase in the cost of production no longer yields an equal or greater increase in income.

Because of the wide variety of cost concepts, it is not possible to deal with all of them in a single section for reason only the following items dealt with for short term benefit.

1. Total variable costs (TVC)

2. Average variable costs (AVC)

3. Marginal costs (MC)

4. Gross margin

5. Benefits cost ratio (BCR)

6. Gross benefits (GB)

7. Marginal rate of return (MRR)

Variable costs: - Variable costs are a function of output and are only incurred if there is production. There is therefore a relationship between the volume of production and costs. For this study variable costs are seed, fertilizer, pesticide, wage rate, and oxen rent if production decisions have to be made of the quantities of variable inputs that must be used to maximize benefits over the short term, only variable costs are relevant since fixed costs remain constant.

Total costs:-Total costs are the sum of the total fixed and total variable costs, for this study of the short term analysis variable only variable cost was taken.

Average costs: - Average or unit costs are the costs per unit such as cost per kilogram or quintal, per hectare, per liter. Average variable and average total costs can, depending on the circumstances, be calculated by dividing the specific cost amount of the corresponding units.

$$
\mathrm{AVC}=T V C / \text { yield of durum wheat }(\mathrm{Kg})
$$

As in short run analysis, focus on the operational cost analysis and the fixed cost is constant then;

$$
\mathrm{AVC}=V C / \text { yield of Durum wheat }(\mathrm{Kg})
$$

The assumption is that for this research the fixed cost is constant and taken the variability among the costs that can be used for validation of benefits for different practices; so that ATC equals to AVC.

Marginal costs: - marginal costs are the extra or additional costs attached to the last unit of output marginal costs are calculated by dividing the change in costs $(\Delta$ costs $)$ by the change in output ( $\Delta$ yield), that is: Marginal costs are only determined by an increase in variable costs. As long as marginal income is bigger than marginal costs, the benefit will be increased.

$$
\mathrm{MC}=\frac{\Delta \mathrm{TC}}{\Delta \mathrm{Q}}
$$

Tells us how much cost rises per unit increase in yield of Durum wheat.

The Marginal cost of any change in output is equal to the shape of the total cost curve along that interval of yield.

If the $\mathrm{MC}>\mathrm{AVC}$; the average cost is rising for a kilogram of durum wheat yield per plot or per hectare. If the $\mathrm{MC}=\mathrm{AVC}$ than the average cost is at its lowest point.

If $\mathrm{MC}<\mathrm{AVC}$; the average cost is falling for a kilogram of yield.

Gross margin:-

Benefit cost ratio: -is an indicator, used in cost-benefit analysis, which attempts to summarize the overall value for money of a Durum wheat production treatment. It is an important tool to assess the economics of farming. It is the ratio of all net value of Durum wheat produced after deducting the costs of different inputs after their summation in the production process.

$$
\mathrm{BCR}=\frac{G B-T V C}{T V C}
$$

Where:

$\mathrm{BCR}=$ benefit cost ratio

$\mathrm{GB}=$ gross benefits

$\mathrm{TVC}=$ total variable cost

The Marginal rate of return: Technically, the marginal rate of return (MRR) is the marginal return or the amount of revenue per additional item, divided by marginal cost (the cost per additional item produced). In other words, it's the amount of additional revenue that a Durum wheat production can expect to earn per each additional Birr that it spends on producing. Using the marginal rate of return, a farmer can determine whether or not its operations have a benefit or loss. The marginal rate of return becomes most powerful when it's used as a decision-making tool. As long as an MRR is greater than one, a farmer can make a profit by producing one additional unit. Because MRR tends to decrease as more and more units are produced, a farmer will maximize its benefits by expanding production until its marginal rate is one. Basically, this is where marginal revenue equals marginal cost $(\mathrm{MR}=\mathrm{MC})$. If a company produces beyond this point, the MRR drops below one $(\mathrm{MR}<1)$, and the company will be spending more per each additional item than it is bringing in revenue. [14] Suggested that a minimum rate of return of $50 \%-100 \%$ is the rate at which farmers may be willing to accept the new technologies or practical shows that the decision to change from extension to the innovation package.

\section{Result and Discussion}

The agronomic result per plot $\left(500^{2}\right)$ indicates that in 
Farm $_{1}$ of Table 2 show highest tiller that farmers practice package treatment was 7.2 while it was 5.1 in $\mathrm{Farm}_{2}$ in extension package A tiller is a stem produced by grass plants, and refers to all shoots that grow after the initial parent shoot grows from a seed. Tillers are segmented, each segment possessing its own two-part leaf. They are involved in vegetative propagation and, in some cases, also seed production); while spike (An ear is the grain-bearing tip part of the stem of a cereal plant, such as wheat. The ear is a spike, consisting of a central stem on which tightly packed rows of flowers grow. These develop into fruits containing the edible seeds. In corn, it is protected by leaves called husks) which was 18.4 on Farm $_{1}$ while 16.9 on Farm $_{2}$ with farmers practices. The highest seed per plant was found in extension package 53.3 while the highest yield was recorded in ATA package $200 \mathrm{Kg}$ in $500^{2}$ (Table 2).

Table 2. Average agronomic data of the validation experiment yield and yield component.

\begin{tabular}{|c|c|c|c|c|c|c|c|c|c|c|}
\hline \multirow{2}{*}{$\begin{array}{l}\text { Experiment } \\
\text { Packages }\end{array}$} & \multicolumn{5}{|l|}{ Farm $_{1}$} & \multicolumn{5}{|l|}{$\operatorname{Farm}_{2}$} \\
\hline & Tillers & Spike & Seeds/plant & TSW & Yield $_{\mathrm{Kg}}$ & Tillers & Spike & seeds/plant & TSW & Yield $_{\mathrm{Kg}}$ \\
\hline ATA & 5.3 & 17.9 & 51.1 & 40 & 200 & 4.9 & 16.4 & 52.6 & 36 & 201 \\
\hline Extension & 5.0 & 18.3 & 53.3 & 40 & 190 & 5.1 & 15.0 & 47.9 & 36 & 193 \\
\hline Farmer & 7.2 & 18.4 & 50.1 & 40 & 154 & 4.2 & 16.9 & 53 & 32 & 159 \\
\hline
\end{tabular}

Source: Own data computed 2019

Table 3 indicates the protein contain of the packages trial in the two sample farms; the percentages of the quality parameters of the protein in percent differ only in the extension package of the Farm 1 was found $13.0 \%$. Each of the hundreds of varieties of wheat cultivated in Ethiopia fall under one of six classes depending on its planting time, harvest, hardiness, color and shape. The protein content of these wheat varieties ranges from 10 to 15 percent; durum wheat is the second highest. One hundred grams of durum wheat have $12.7 \%$ grams of protein on average in the three different packages.

Table 3. Average protein test result of validation experimental packages.

\begin{tabular}{lllllll}
\hline \multirow{2}{*}{ Quality parameter } & Farm $_{1}$ & & & Farm $_{2}$ & & \\
\cline { 2 - 7 } & ATA & Extension & Farmer & ATA & Extension & Farmer \\
\hline Protein (\%) & 12.7 & 13.0 & 12.8 & 12.8 & 12.6 & 12.7 \\
\hline
\end{tabular}

Source: Own data computed 2019

The results indicated in Table 4 that on average the total variable costs varies ATA packages with the two others (extension package and farmers practices); the first one had 16,888.50 Eth. Birr while the two had similar costs that was $14,624.25$ Eth. Birr because of application of inputs are almost similar. On the other hand the yield varies accordingly 3830,4010 and 3130 kilograms per hectare was found in the packages of the treatment for extension, ATA and Farm practice respectively. The net revenue of the experiments was compared in Eth. Birr per $\mathrm{h}^{-1}$ with the grain price per $\mathrm{Kg}$ was 17.00 while the straw price was 3.75 Eth. Birr (See Annex). The net gain for extension, ATA and farmers practices packages were found 53,498, 54,600.25 and 41,126 Eth. Birr per hectare in the durum wheat production system of on farm trial in Minjar-shenkora districts of Amhara regional state of Ethiopia. As the result indicates the ATA package has a 1,102 benefits as compared to the extension package; yet the ATA has applied different chemicals and fertilizer that can have an implication on long term negative effect it should be tested for its different implicit implication to the other sides of monitory terms (Table 4).

As long as an MRR is greater than one, a production can make a profit by producing one additional unit. Because MRR tends to decrease as more and more units are produced, a farmer will maximize its profits by expanding production until its marginal rate is one. In other words; MRR is the rate of return for a marginal increase in investment on durum wheat; roughly, this is the additional output resulting from a one-unit increase in the use of a variable input (seed, fertilizer, labor, pesticides, or oxen) -one of them, while the other inputs are constant. The MRR of the ATA package is profitable whenever there is a shift from the extension package.

Table 4. Partial budget analysis.

\begin{tabular}{|c|c|c|c|c|c|c|c|c|c|}
\hline \multirow{3}{*}{ Inputs costs } & \multicolumn{9}{|l|}{ Category } \\
\hline & \multicolumn{3}{|c|}{ Extension Package } & \multicolumn{3}{|c|}{ ATA Package } & \multicolumn{3}{|c|}{ Farmers Practice } \\
\hline & Farm1 & Farm2 & Average & Farm1 & Farm2 & Average & Farm1 & Farm2 & Average \\
\hline Seed/fertilizers/pesticides (Birr/ha) & 6465.00 & 6030.50 & 6247.75 & 9130.00 & $8,652.00$ & 8891.00 & 6465.00 & 6030.50 & 6247.75 \\
\hline Seed & 1700.00 & 1700.00 & 1700.00 & 1700.00 & $1,700.00$ & 1700.00 & 1700.00 & $1,700.00$ & 1700.00 \\
\hline Fertilize & 4765.00 & 4330.50 & 4547.75 & 5430.00 & $4,952.00$ & 5191.00 & 4765.00 & $4,330.50$ & 4547.75 \\
\hline Fungicide & 0.00 & 0.00 & 0.00 & 750.00 & 750.00 & 750.00 & 0.00 & 0.00 & 0.00 \\
\hline Herbicide & 0.00 & 0.00 & 0.00 & $1,250.00$ & $1,250.00$ & 1250.00 & 0.00 & 0.00 & 0.00 \\
\hline Human Labor costs (Birr/ha) & $5,800.00$ & 4495.00 & 5147.50 & $4,600.00$ & $4,895.00$ & 4747.50 & $5,800.00$ & $4,495.00$ & 5147.50 \\
\hline Oxen plowing and threshing (Birr/ha) & $3,300.00$ & $3,200.00$ & 3250.00 & $3,300.00$ & $3,200.00$ & 3250.00 & $3,300.00$ & $3,200.00$ & 3250.00 \\
\hline Total inputs costs (Birr/ha) Variable & $15,565.00$ & $13,725.50$ & 14645.25 & $17,030.00$ & $16,747.00$ & 16888.50 & $15,565.00$ & $13,725.50$ & 14645.25 \\
\hline Yield $(\mathrm{Kg} / \mathrm{ha})$ & 3860 & 3800 & 3830 & 4020 & 4000 & 4010 & 3180 & 3080 & 3130 \\
\hline Straw & 828 & 790 & 809 & 872 & 898 & 885 & 672 & 694 & 683 \\
\hline
\end{tabular}




\begin{tabular}{|c|c|c|c|c|c|c|c|c|c|}
\hline \multirow{3}{*}{ Inputs costs } & \multicolumn{9}{|l|}{ Category } \\
\hline & \multicolumn{3}{|c|}{ Extension Package } & \multicolumn{3}{|c|}{ ATA Package } & \multicolumn{3}{|c|}{ Farmers Practice } \\
\hline & Farm1 & Farm2 & Average & Farm1 & Farm2 & Average & Farm1 & Farm2 & Average \\
\hline Grain value (Birr/ha) & $65,620.00$ & $64,600.00$ & 65110.00 & $68,340.00$ & $68,000.00$ & 68170.00 & $54,060.00$ & $52,360.00$ & 53210.00 \\
\hline Straw value (Birr/ha) & $3,105.00$ & $2,962.50$ & 3033.75 & $3,270.00$ & $3,367.50$ & 3318.75 & $2,520.00$ & $2,602.50$ & 2561.25 \\
\hline Total revenue (Birr/ha) & 68725.00 & $67,562.50$ & 68143.75 & $71,610.00$ & $71,367.50$ & $71,488.75$ & $56,580.00$ & $54,962.50$ & 55771.25 \\
\hline Net revenue $(\mathrm{Birr} / \mathrm{ha})_{1}$ & $53,160.00$ & $53,837.00$ & $53,498.50$ & $54,580.00$ & $54,620.50$ & $54,600.25$ & $41,015.00$ & $41,237.00$ & $41,126.00$ \\
\hline Benefit-Cost Ratio & 3.42 & 3.92 & 3.67 & 3.20 & 3.26 & 3.23 & 2.64 & 3.00 & 2.82 \\
\hline Costs that vary ${ }_{2}$ & $10,565.00$ & $8,825.50$ & 9695.25 & $10,030.00$ & $9,847.00$ & 9938.50 & $10,565.00$ & $8,825.50$ & 9695.25 \\
\hline Net revenue $(\mathrm{Birr} / \mathrm{ha})_{2}$ & $58,160.00$ & $58,737.00$ & 58448.5 & $61,580.00$ & $61,520.50$ & $61,550.25$ & $46,015.00$ & $46,137.00$ & 46076.00 \\
\hline $\mathrm{MNR}_{2}$ & - & - & - & $3,420.00$ & $2,783.50$ & $3,101.75$ & $-12,145.00$ & $-12,600.00$ & -12372.5 \\
\hline $\mathrm{MVC}_{2}$ & - & - & - & -535.00 & $1,021.50$ & 243.25 & 0.00 & 0.00 & 0.00 \\
\hline $\mathrm{MRR}_{2}$ & - & - & - & $-639.3 \%$ & $272.5 \%$ & $1275.1 \%$ & - & - & - \\
\hline Rank & & & 2 & & & 1 & & & 3 \\
\hline
\end{tabular}

Source: own data computed 2019

N.B.

$$
\mathrm{MRR}=\frac{\mathrm{MNR} 2}{\mathrm{MVC} 2}
$$

As one of the starting thoughts was if it will be at all feasible to sell the amounts of units in a realistic time to break even and make a profit from durum wheat production, we come to the limitations of the break-even analysis. While it gives us theoretical number on, for example, how much the producers have to sell to reach the break-even point or make a specific profit, it does not take into account the general market. All in all, the break-even point and its different extensions to calculate the break-even point in units, the break-even points in sales value, the target sales in units, and also the margin of safety was a good starting point to analyze potential level of sales. Margin of safety (MOS) is the difference between actual sales and break-even sales. In other words, all sales revenue above the break-even point represents the margin of safety.

In the first case of Table 5 indicates that the result for break-even yield was found $861.47,993.44$ and $861.49 \mathrm{Kg}$ of durum wheat per $\mathrm{h}^{-1}$ for extension, ATA and farmers practice packages while the break-even price was $3.82,4.21$ and 4.68 as the result indicates respectively (Table 5).

The margin of safety is how much output can fall before the production reaches its break-even point. If a farmer in the durum wheat production system applies the three different package treatments it will have 2968.51, 3016.88 and $2268.51 \mathrm{Kg}$ per $\mathrm{h}^{-1}$ for extension, ATA and farmer practice packages (Table 5).

In calculating the efficiency ratio of durum wheat for the three different packages for smallholder producers the on farm trial results indicate positive returns for all but when compare to each extension package is more beneficial. We applied expenss/revenue for testing efficiency ratio. Table 5; result indicates that the efficiency ratio was found 0.27 , 0.31 and 0.36 for extension, ATA and farmer practices package respectively. For instance in the case extension package which was 0.27 Birr that states cost of the producers was 0.27 Birr to generate 1 Birr of revenue (Table 5). The lower the ratio in the production process, the better; $50 \%$ is generally regarded as the maximum optimal ratio. An increase in the efficiency ratio indicates either increasing costs or decreasing revenues of the durum wheat producers.

Table 5. Break-even analysis.

\begin{tabular}{|c|c|c|c|c|c|c|c|c|c|}
\hline \multirow{2}{*}{ Category } & \multicolumn{3}{|c|}{ Extension Package } & \multicolumn{3}{|c|}{ ATA Package } & \multicolumn{3}{|c|}{ Farmers Practice } \\
\hline & Farm $_{1}$ & $\operatorname{Farm}_{2}$ & Average & Farm $_{1}$ & $\operatorname{Farm}_{2}$ & Average & $\operatorname{Farm}_{1}$ & $\operatorname{Farm}_{2}$ & Average \\
\hline Breakeven yield & 915.59 & 807.38 & 861.49 & 1001.76 & 985.12 & 993.44 & 915.59 & 807.38 & 861.49 \\
\hline Breakeven price & 4.03 & 3.61 & 3.82 & 4.24 & 4.19 & 4.21 & 4.89 & 4.46 & 4.68 \\
\hline Marginal safety & 2944.41 & 2992.62 & 2968.51 & 3018.24 & 3014.88 & 3016.56 & 2264.41 & 2272.62 & 2268.51 \\
\hline Margin of safety $\%$ & 76.28 & 78.75 & 77.52 & 75.08 & 75.37 & 75.23 & 71.21 & 73.79 & 72.50 \\
\hline Efficiency ratio & 0.29 & 0.25 & 0.27 & 0.31 & 0.31 & 0.31 & 0.38 & 0.33 & 0.36 \\
\hline
\end{tabular}

Source: own data computed 2019

NB: Marginal safety [current output - break-even output]

\section{Conclusion and Recommendations}

According to the effect of UREA fertilizer on durum wheat biological and economical yield, and the other traits result of the 2018 validation test, there was no significant difference between ATA UREA fertilizer recommendation rate $(300 \mathrm{Kg} / \mathrm{ha})$ and extension package UREA fertilizer recommendation rate $(250 \mathrm{Kg} / \mathrm{ha})$. Last year validation result was the same, but the ATA UREA fertilizer recommendation rate was higher than this year which was $350 \mathrm{Kg} / \mathrm{ha}$. Therefore, as long as there was no significant difference effect of urea fertilizer rate on durum wheat yield and yield related traits between innovation and extension recommendation package, use of extension recommendation package rate is advantageous for small holder farmers in terms of cost and environmental safeness.

The statistical result indicates that the ATA packages had a benefit of 1,102 Eth. Birr/ha as compared to extension recommendation package; yet it applies different chemical to gain this amount which has a negative implication to the environment, but if this is applied to economics of scale the 
gross return might increase.

\section{Appendix}

Table A1. Farm 1.

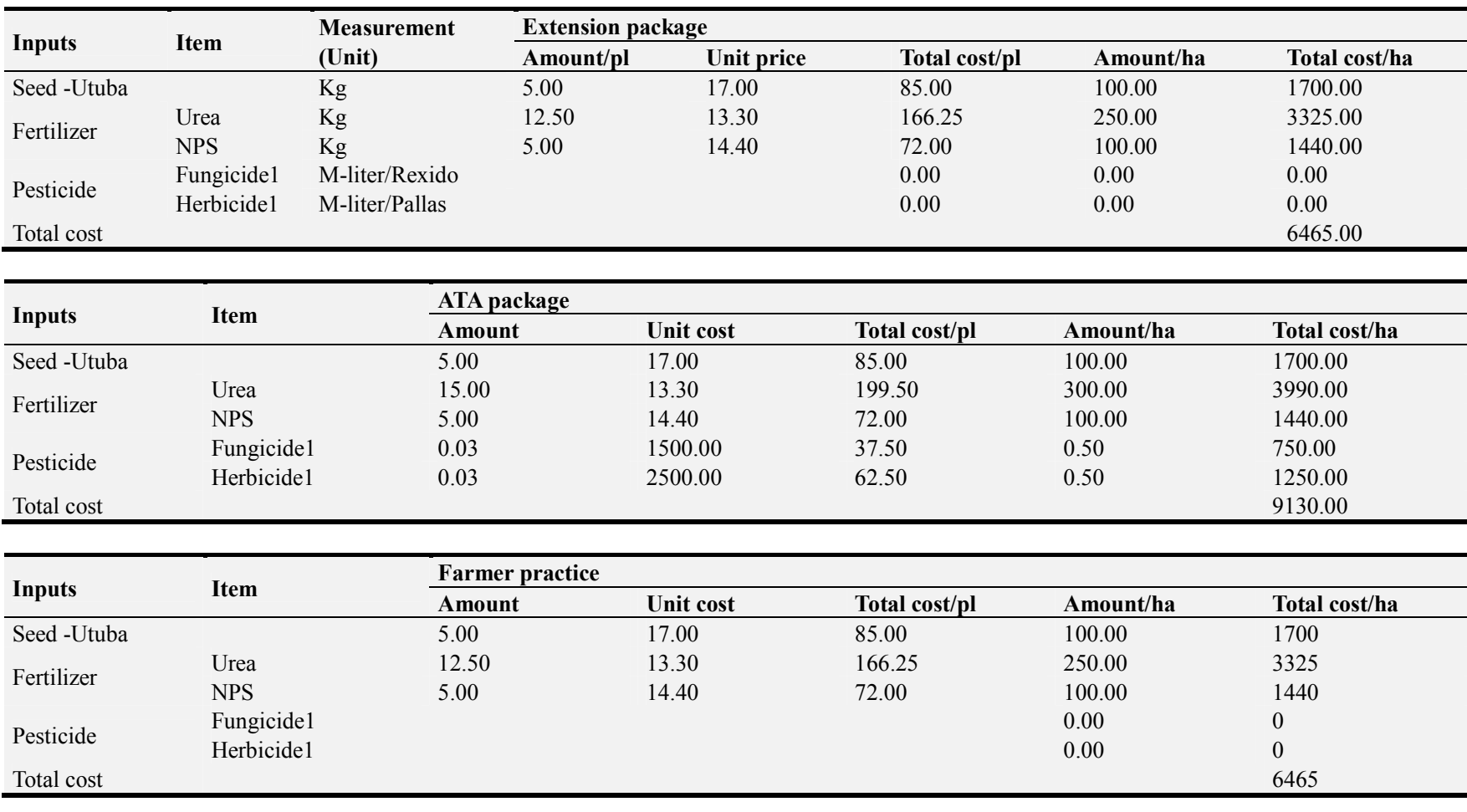

\begin{tabular}{llllllll}
\hline \multirow{2}{*}{ Inputs } & \multirow{2}{*}{ Item } & Measurement & \multicolumn{2}{l}{ Extension package } & & & \\
\cline { 3 - 8 } & & (Unit) & Amount/pl & Unit price & Total cost/pl & Amount/ha & Total cost/ha \\
\hline Seed -Utuba & & $\mathrm{Kg}$ & 5.00 & 17.00 & 85.00 & 100.00 & 1700.00 \\
Fertilizer & Urea & $\mathrm{Kg}$ & 12.50 & 13.30 & 166.25 & 250.00 & 3325.00 \\
& NPS & $\mathrm{Kg}$ & 5.00 & 14.40 & 72.00 & 100.00 & 1440.00 \\
Pesticide & Fungicide1 & M-liter/Rexido & & & 0.00 & 0.00 & 0.00 \\
Total cost & Herbicide1 & M-liter/Pallas & & & 0.00 & 0.00 & 0.00 \\
\hline
\end{tabular}

\begin{tabular}{|c|c|c|c|c|c|c|}
\hline \multirow{2}{*}{ Inputs } & \multirow{2}{*}{ Item } & \multicolumn{5}{|c|}{ ATA package } \\
\hline & & Amount & Unit cost & Total cost $/ \mathrm{pl}$ & Amount/ha & Total cost $/ \mathrm{ha}$ \\
\hline Seed -Utuba & & 5.00 & 17.00 & 85.00 & 100.00 & 1700.00 \\
\hline \multirow{2}{*}{ Fertilizer } & Urea & 15.00 & 13.30 & 199.50 & 300.00 & 3990.00 \\
\hline & NPS & 5.00 & 14.40 & 72.00 & 100.00 & 1440.00 \\
\hline \multirow{2}{*}{ Pesticide } & Fungicide1 & 0.03 & 1500.00 & 37.50 & 0.50 & 750.00 \\
\hline & Herbicide1 & 0.03 & 2500.00 & 62.50 & 0.50 & 1250.00 \\
\hline Total cost & & & & & & 9130.00 \\
\hline \multirow{2}{*}{ Inputs } & \multirow{2}{*}{ Item } & \multicolumn{5}{|c|}{ Farmer practice } \\
\hline & & Amount & Unit cost & Total cost $/ \mathrm{pl}$ & Amount/ha & Total cost/ha \\
\hline Seed -Utuba & & 5.00 & 17.00 & 85.00 & 100.00 & 1700 \\
\hline \multirow{2}{*}{ Fertilizer } & Urea & 12.50 & 13.30 & 166.25 & 250.00 & 3325 \\
\hline & NPS & 5.00 & 14.40 & 72.00 & 100.00 & 1440 \\
\hline \multirow{2}{*}{ Pesticide } & Fungicide 1 & & & & 0.00 & 0 \\
\hline & Herbicide1 & & & & 0.00 & 0 \\
\hline Total cost & & & & & & 6465 \\
\hline
\end{tabular}

\begin{tabular}{|c|c|c|c|c|c|c|}
\hline \multirow{2}{*}{ Inputs } & \multirow{2}{*}{ Item } & \multirow{2}{*}{ Unit of measurement (Unit) } & \multicolumn{4}{|c|}{ Extension Package } \\
\hline & & & Amount & Unit cost & Total cost/pl & Total cost/ha \\
\hline \multicolumn{7}{|l|}{ Labor } \\
\hline Planting & & Days (hr) & 1 & 150 & 150.00 & 600.00 \\
\hline \multirow{2}{*}{ Fertilizer application } & $1 \mathrm{st}$ & Days (hr) & 1 & 150 & 150.00 & 300.00 \\
\hline & 2nd & Days (hr) & 1 & 150 & 150.00 & 300.00 \\
\hline
\end{tabular}




\begin{tabular}{|c|c|c|c|c|c|c|}
\hline \multirow{2}{*}{ Inputs } & \multirow{2}{*}{ Item } & \multirow{2}{*}{ Unit of measurement (Unit) } & \multicolumn{4}{|c|}{ Extension Package } \\
\hline & & & Amount & Unit cost & Total cost $/ \mathbf{p l}$ & Total cost $/ \mathrm{ha}$ \\
\hline \multirow{2}{*}{ Hand weeding } & 1 st & Days (hr) & 1 & 150 & 150.00 & 1200.00 \\
\hline & 2 nd & Days (hr) & 1 & 150 & 150.00 & 600.00 \\
\hline Fungicide & $1 \mathrm{st}$ & & 0 & 0 & 0 & 0 \\
\hline Herbicide & 1 st & Days (hr) & 0 & 0 & 0 & 0 \\
\hline Total & & & & & & $3,000.00$ \\
\hline
\end{tabular}

\begin{tabular}{|c|c|c|c|c|c|c|}
\hline \multirow{2}{*}{ Inputs } & \multirow{2}{*}{ Item } & \multirow{2}{*}{ Unit of measurement (Unit) } & \multicolumn{4}{|c|}{ ATA package } \\
\hline & & & Amount & Unit cost & Total cost $/ \mathrm{pl}$ & Total cost $/ \mathrm{ha}$ \\
\hline \multicolumn{7}{|l|}{ Labor } \\
\hline Planting & & Days (hr) & 1 & 150 & 150.00 & 600.00 \\
\hline \multirow{2}{*}{ Fertilizer application } & $1 \mathrm{st}$ & Days (hr) & 1 & 150 & 150.00 & 300.00 \\
\hline & $2 \mathrm{nd}$ & Days (hr) & 1 & 150 & 150.00 & 300.00 \\
\hline \multirow{2}{*}{ Hand weeding } & $1 \mathrm{st}$ & Days (hr) & 0 & 0 & 0.00 & 0.00 \\
\hline & 2nd & Days (hr) & 0 & 0 & 0.00 & 0.00 \\
\hline Fungicide & 1 st & & 1 & 150 & 150.00 & 300.00 \\
\hline Herbicide & $1 \mathrm{st}$ & Days (hr) & 1 & 150 & 150.00 & 300.00 \\
\hline Total & & & & & & $1,800.00$ \\
\hline \multirow{2}{*}{ Inputs } & \multirow{2}{*}{ Item } & \multirow{2}{*}{ Unit of measurement (Unit) } & \multicolumn{4}{|c|}{ Farmers practices } \\
\hline & & & Amount & Unit cost & Total cost $/ \mathrm{pl}$ & Total cost $/ \mathrm{ha}$ \\
\hline \multicolumn{7}{|l|}{ Labor } \\
\hline Planting & & Days (hr) & 1 & 150 & 150.00 & 600.00 \\
\hline \multirow{2}{*}{ Fertilizer application } & $1 \mathrm{st}$ & Days (hr) & 1 & 150 & 150.00 & 300.00 \\
\hline & 2 nd & Days (hr) & 1 & 150 & 150.00 & 300.00 \\
\hline \multirow{2}{*}{ Hand weeding } & $1 \mathrm{st}$ & Days (hr) & 1 & 150 & 150.00 & 1200.00 \\
\hline & 2 nd & Days (hr) & 1 & 150 & 150.00 & 600.00 \\
\hline Fungicide & $1 \mathrm{st}$ & & 0 & 0 & 0 & 0 \\
\hline Herbicide & $1 \mathrm{st}$ & Days (hr) & 0 & 0 & 0 & 0 \\
\hline Total & & & & & & $3,000.00$ \\
\hline
\end{tabular}

\begin{tabular}{|c|c|c|c|c|c|c|}
\hline \multirow{2}{*}{ Inputs } & \multirow{2}{*}{ Item } & \multirow{2}{*}{ Unit of measurement (Unit) } & \multicolumn{4}{|c|}{ Extension Package } \\
\hline & & & Amount & Unit cost & Total cost $/ \mathbf{p l}$ & Total cost/ha \\
\hline \multicolumn{7}{|l|}{ Labor } \\
\hline Harvesting & & Days (hr) & 1 & 200 & 200 & 1600 \\
\hline Transporting & & Days (hr) & 1 & 200 & 200 & 400 \\
\hline Threshing & & Days (hr) & 1 & 200 & 200 & 800 \\
\hline \multirow[t]{4}{*}{ Oxen for plowing } & & & & & & 0 \\
\hline & $1 \mathrm{st}$ & Oxen pair & 1 & 200 & 200 & 800 \\
\hline & $2 \mathrm{nd}$ & Oxen pair & 1 & 200 & 200 & 800 \\
\hline & 3 rd & Oxen pair & 1 & 200 & 200 & 800 \\
\hline Threshing & No. of livestock & No. & 5 & 100 & 500 & 900 \\
\hline Total & & & & & & $6,100.00$ \\
\hline \multirow{2}{*}{ Inputs } & \multirow{2}{*}{ Item } & \multirow{2}{*}{ Unit of measurement (Unit) } & \multicolumn{4}{|c|}{ ATA package } \\
\hline & & & Amount & Unit cost & Total cost $/ \mathbf{p l}$ & Total cost $/ \mathrm{ha}$ \\
\hline \multicolumn{7}{|l|}{ Labor } \\
\hline Harvesting & & Days (hr) & 1 & 200 & 200 & 1600 \\
\hline Transporting & & Days (hr) & 1 & 200 & 200 & 400 \\
\hline Threshing & & Days (hr) & 1 & 200 & 200 & 800 \\
\hline \multirow[t]{4}{*}{ Oxen for plowing } & & & & & 0 & \\
\hline & $1 \mathrm{st}$ & Oxen pair & 1 & 200 & 200 & 800 \\
\hline & 2 nd & Oxen pair & 1 & 200 & 200 & 800 \\
\hline & $3 \mathrm{rd}$ & Oxen pair & 1 & 200 & 200 & 800 \\
\hline Threshing & No. of livestock & No. & 5 & 100 & 500 & 900 \\
\hline Total & & & & & & $6,100.00$ \\
\hline \multirow{2}{*}{ Inputs } & \multirow{2}{*}{ Item } & \multirow{2}{*}{ Unit of measurement (Unit) } & \multicolumn{4}{|c|}{ Farmers practices } \\
\hline & & & Amount & Unit cost & Total cost $/ \mathrm{pl}$ & Total cost $/ \mathrm{ha}$ \\
\hline \multicolumn{7}{|l|}{ Labor } \\
\hline Harvesting & & Days (hr) & 1 & 200 & 200 & 1600 \\
\hline Transporting & & Days (hr) & 1 & 200 & 200 & 400 \\
\hline \multirow{2}{*}{$\begin{array}{l}\text { Threshing } \\
\text { Oxen for plowing }\end{array}$} & & Days (hr) & 1 & 200 & 200 & 800 \\
\hline & $1 \mathrm{st}$ & Oxen pair & 1 & 200 & 200 & 800 \\
\hline
\end{tabular}




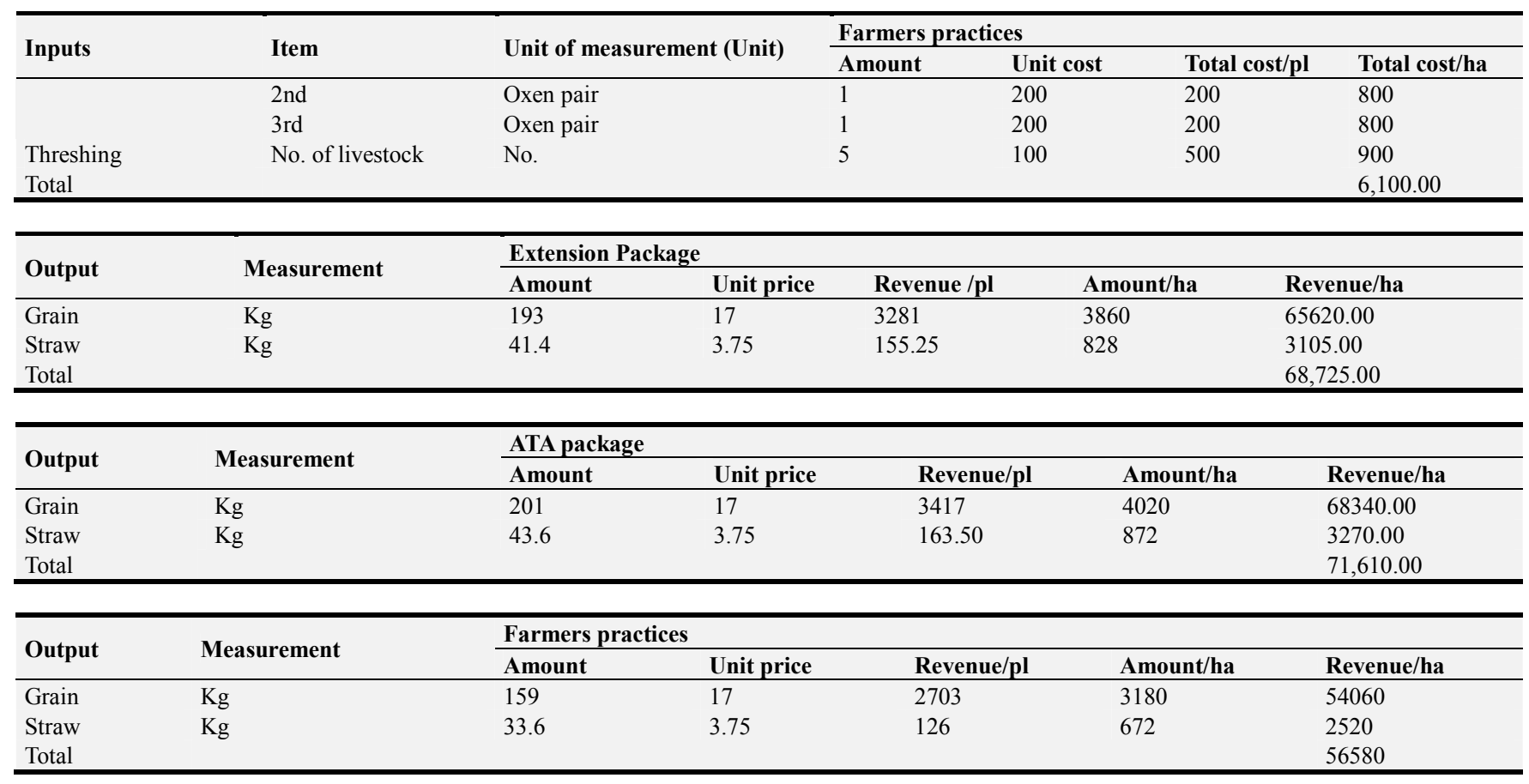

Table A2. Farm 2.

\begin{tabular}{|c|c|c|c|c|c|c|c|}
\hline \multirow{2}{*}{ Inputs } & \multirow{2}{*}{ Item } & \multirow{2}{*}{$\begin{array}{l}\text { Measurement } \\
\text { (Unit) }\end{array}$} & \multicolumn{5}{|c|}{ Extension package } \\
\hline & & & Amount/pl & Unit cost & Total cost $/ \mathrm{pl}$ & Amount/ha & Total cost $/ \mathrm{ha}$ \\
\hline Seed-Utuba & & & 5 & 17.00 & 85.00 & 100 & 1700.00 \\
\hline \multirow{2}{*}{ Fertilizer } & Urea & $\mathrm{Kg}$ & 13 & 12.43 & 155.38 & 250 & 3107.50 \\
\hline & NPS & $\mathrm{Kg}$ & 5 & 12.23 & 61.15 & 100 & 1223.00 \\
\hline \multirow[t]{2}{*}{ Pesticide } & Fungicide2 & Liter & 0 & 0.00 & 0.00 & 0 & 0.00 \\
\hline & Herbicide1 & M-liter/Pallas & 0 & 0.00 & 0.00 & 0 & 0.00 \\
\hline Total cost & & & & & & & 6030.50 \\
\hline
\end{tabular}

\begin{tabular}{lllllll}
\hline \multirow{2}{*}{ Inputs } & \multirow{2}{*}{ Item } & ATA package & & & & \\
\cline { 3 - 7 } & & Amount & Unit cost & Total cost & Amount/ha & Total cost/ha \\
\hline Seed-Utuba & & 5 & 17.00 & 85.00 & 100.00 & 1700.00 \\
Fertilizer & Urea & 15 & 12.43 & 186.45 & 300.00 & 3729.00 \\
Pesticide & NPS & 5 & 12.23 & 61.15 & 100.00 & 1223.00 \\
& Fungicide2 & 0.03 & 1500.00 & 37.50 & 0.50 & 750.00 \\
Total cost & Herbicide1 & 0.03 & 2500.00 & 62.50 & 0.50 & 1250.00 \\
\hline
\end{tabular}

\begin{tabular}{|c|c|c|c|c|c|c|}
\hline \multirow{2}{*}{ Inputs } & \multirow{2}{*}{ Item } & \multicolumn{4}{|l|}{$\begin{array}{l}\text { Farmer practice } \\
\text { Amount }\end{array}$} & \multirow[b]{2}{*}{ Total cost $/ \mathrm{ha}$} \\
\hline & & Amount & Unit cost & Total cost & Amount/ha & \\
\hline Seed-Utuba & & 5.00 & 17.00 & 85.00 & 100 & 1700.00 \\
\hline \multirow{2}{*}{ Fertilizer } & Urea & 12.50 & 12.43 & 155.38 & 250 & 3107.50 \\
\hline & NPS & 5 & 12.23 & 61.15 & 100 & 1223.00 \\
\hline \multirow[t]{2}{*}{ Pesticide } & Fungicide2 & 0.00 & 0.00 & 0.00 & 0 & 0.00 \\
\hline & Herbicide 1 & 0.00 & 0.00 & 0.00 & 0 & 0.00 \\
\hline \multicolumn{2}{|l|}{ Total cost } & & & & & 6030.50 \\
\hline \multirow{2}{*}{ Inputs } & \multirow{2}{*}{ Item } & \multirow{2}{*}{ Unit of measurement (Unit) } & \multicolumn{2}{|c|}{ Extension Package } & & \\
\hline & & & Amount/pl & Unit cost & Total cost $/ \mathrm{pl}$ & Total cost $/ \mathrm{ha}$ \\
\hline \multicolumn{7}{|l|}{ Labor } \\
\hline \multirow{2}{*}{ Planting } & & Days (hr) & 1 & 175 & 175.00 & 525.00 \\
\hline & $1 \mathrm{st}$ & Days (hr) & 1 & 100 & 100.00 & 200.00 \\
\hline Fertilizer application & 2 nd & Days (hr) & 1 & 100 & 100.00 & 200.00 \\
\hline \multirow{2}{*}{ Hand weeding } & $1 \mathrm{st}$ & Days (hr) & 1 & 150 & 150.00 & 900.00 \\
\hline & $2 \mathrm{nd}$ & Days (hr) & 1 & 150 & 150.00 & 900.00 \\
\hline Fungicide & $1 \mathrm{st}$ & & 0 & 0 & 0.00 & 0.00 \\
\hline Herbicide & $1 \mathrm{st}$ & Days (hr) & 0 & 0 & 0.00 & 0.00 \\
\hline Total & & & & & & $2,725.00$ \\
\hline
\end{tabular}




\begin{tabular}{|c|c|c|c|c|c|c|}
\hline \multirow{2}{*}{ Inputs } & \multirow{2}{*}{ Item } & \multirow{2}{*}{ Unit of measurement (Unit) } & \multicolumn{2}{|c|}{ ATA package } & \multirow[b]{2}{*}{ Total cost } & \multirow[b]{2}{*}{ Total cost/ha } \\
\hline & & & Amount & Unit cost & & \\
\hline \multicolumn{7}{|l|}{ Labor } \\
\hline Planting & & Days (hr) & 1 & 175 & 175.00 & 525.00 \\
\hline \multirow{2}{*}{ Fertilizer application } & $1 \mathrm{st}$ & Days (hr) & 1 & 100 & 100.00 & 200.00 \\
\hline & 2 nd & Days (hr) & 1 & 100 & 100.00 & 200.00 \\
\hline \multirow{2}{*}{ Hand weeding } & $1 \mathrm{st}$ & Days (hr) & 1 & 150 & 150.00 & 900.00 \\
\hline & $2 \mathrm{nd}$ & Days (hr) & 1 & 150 & 150.00 & 900.00 \\
\hline Fungicide & $1 \mathrm{st}$ & & 1 & 100 & 100.00 & 200 \\
\hline Herbicide & 1 st & Days (hr) & 1 & 100 & 100.00 & 200 \\
\hline Total & & & & & & $3,125.00$ \\
\hline \multirow{2}{*}{ Inputs } & \multirow{2}{*}{ Item } & \multirow{2}{*}{$\begin{array}{l}\text { Unit of measurement } \\
\text { (Unit) }\end{array}$} & \multicolumn{2}{|c|}{ Farmers practices } & & \\
\hline & & & Amount & Unit cost & Total cost & Total cost $/ \mathrm{ha}$ \\
\hline \multicolumn{7}{|l|}{ Labor } \\
\hline Planting & & Days (hr) & 1 & 175 & 175.00 & 525.00 \\
\hline \multirow{2}{*}{ Fertilizer application } & $1 \mathrm{st}$ & Days (hr) & 1 & 100 & 100.00 & 200.00 \\
\hline & 2 nd & Days (hr) & 1 & 100 & 100.00 & 200.00 \\
\hline \multirow{2}{*}{ Hand weeding } & $1 \mathrm{st}$ & Days (hr) & 1 & 150 & 150.00 & 900.00 \\
\hline & 2 nd & Days (hr) & 1 & 150 & 150.00 & 900.00 \\
\hline Fungicide & 1st & & & & 0.00 & 0.00 \\
\hline Herbicide & $1 \mathrm{st}$ & Days (hr) & & & 0.00 & 0.00 \\
\hline Total & & & & & & 2725.00 \\
\hline
\end{tabular}

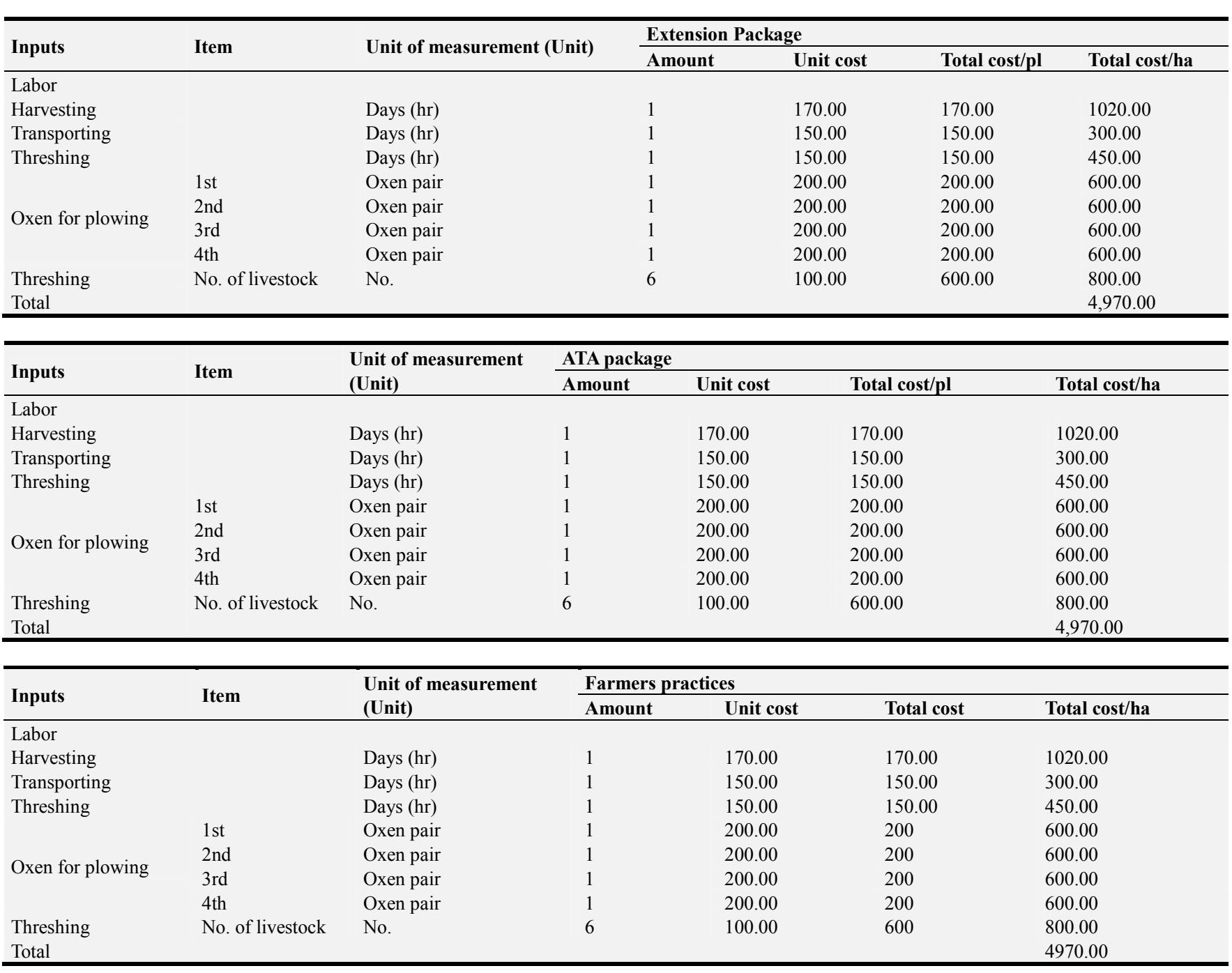




\begin{tabular}{|c|c|c|c|c|c|c|}
\hline \multirow{2}{*}{ Output } & \multirow{2}{*}{ Measurement } & \multicolumn{5}{|c|}{ Extension Package } \\
\hline & & Amount & Unit price & Revenue/pl & Amount/ha & Revenue/ha \\
\hline Grain & $\mathrm{Kg}$ & 190 & 17.00 & 3230.00 & 3800 & 64600.00 \\
\hline Straw & $\mathrm{Kg}$ & 39.5 & 3.75 & 148.13 & 790.00 & 2962.50 \\
\hline Total & & & & & & $67,562.50$ \\
\hline
\end{tabular}

\begin{tabular}{|c|c|c|c|c|c|c|}
\hline \multirow{2}{*}{ Output } & \multirow{2}{*}{ Measurement } & \multicolumn{5}{|c|}{ ATA package } \\
\hline & & Amount & Unit price & Revenue/pl & Amount/ha & Revenue/ha \\
\hline Grain & $\mathrm{Kg}$ & 200 & 17.00 & 3400.00 & 4000 & 68000.00 \\
\hline Straw & $\mathrm{Kg}$ & 44.9 & 3.75 & 168.38 & 898.00 & 3367.50 \\
\hline Total & & & & & & $71,367.50$ \\
\hline
\end{tabular}

\begin{tabular}{llllll}
\hline \multirow{2}{*}{ Output } & \multirow{2}{*}{ Measurement } & Farmers practices & & & \\
\cline { 3 - 6 } & & Amount & Unit price & Revenue/pl & Amount/ha \\
\hline Grain & $\mathrm{Kg}$ & 154 & 17.00 & 2618.00 & 3080 \\
Straw & $\mathrm{Kg}$ & 34.7 & 3.75 & 130.13 & 694 \\
Total & & & & & \\
\hline
\end{tabular}

\section{References}

[1] Triticum durum" Germplasm Resources Information Network (GRIN). Agricultural Research Service (ARS), United States Department of Agriculture (USDA). Retrieved 11 December 2017.

[2] Global durum wheat use trending upward". world-grain.com. Retrieved 21 March 2018.

[3] Colomba MS, Gregorini A (2011) Genetic diversity analysis of the Graziella Ra, Triticumturgidum L. subsp. durum (Desf.) Husn. (Poales, Poaceae). Biodiversity Journal 2 (2): 73-84.

[4] Elias, E. M. Durum wheat products. In Durum Wheat Quality in the Mediterranean Region; Di Fonzo, N., Kaan, F., Nachit, M., Eds.; CIHEAM: Zaragoza, Spain, 1995; Volume 22, pp. 23-31. [Google Scholar].

[5] National Research Council. Lost Crops of Africa: Volume I: Grains; The National Academies Press: Washington, DC, USA, 1996. [Google Scholar].

[6] Luo, M. C.; Yang, Z. L.; You, F. M. The structure of wild and domesticated emmer wheat populations, gene flow between them and the site of emmer domestication. Theor. Appl. Genet. 2007, 114, 947-959. [Google Scholar] [CrossRef].

[7] Kabbaj, H.; Sall, A. T.; Al-Abdallat, A.; Geleta, M.; Amri, A.; Filali-Maltouf, A.; Belkadi, B.; Ortiz, R.; Bassi, F. M. Genetic Diversity within a Global Panel of Durum Wheat (Triticum durum) Landraces and Modern Germplasm Reveals the History of Alleles Exchange. Front. Plant Sci. 2017, 8, 1277. [Google Scholar] [CrossRef] [PubMed].
[8] Mengistu, D. K.; Kirosa, Y. A. Y.; Pè, M. E. Phenotypic diversity in Ethiopian durum wheat (Triticum turgidum var. durum) landraces. Crop J. 2015, 3, 190-199. [Google Scholar] [CrossRef].

[9] Evan School Policy Analysis and Research (EPAR). Wheat Value Chain: Ethiopia. Available online: https://evans.uw.edu/sites/default/files/EPAR_UW_204_Whea t_Ethiopia_07272012.pdf (accessed on 24 December 2016).

[10] CSA, 2018. Central Statistics Agency, Agricultural Sample Survey Report on Area and Productionof Major Crops Private Peasant Holdings, Meher Season, Addis Ababa, Ethiopia.

[11] Zilić S, Barać M, Pešić M, Dodig D, Ignjatović-Micić D (2011). "Characterization of proteins from grain of different bread and durum wheat genotypes". Int J Mol Sci. 12 (9): 5878 94. doi: 10.3390/ijms12095878. PMC 3189758. PMID 22016634

[12] https://en.wikipedia.org/wiki/Durum (Accessed in 27th March 2019).

[13] MOA (2015) Ministry of Agriculture, Plant Variety Release, Protection and Seed Quality Control Directorate, Crop Variety Register, Issue No. 17, June 2014, Addis Ababa, Ethiopia; pp. 330 .

[14] AmsalTarekegne, Turner DG, GetinetGebeyehu (1995) Improvement in yield of bread wheat cultivars released in Ethiopia from 1949 to 1987. African Crop Science Journal 3 (1): 41-49.

[15] Gebre-Maryam H (1991) Wheat production \& research in Ethiopia. In: Wheat Research in Ethiopia: A Historical Perspective. Gebre-Mariam H, Tanner DG, et al. (Eds.), IAR/CIMMYT, Addis Ababa, Ethiopia; p. 1-15. 